UC-70

Issued: September 1987

LA--11097-MS

DE88 000173

\title{
Controlled Blasting and Its Implications for the NNWSI Project Exploratory Shaft
}

Edward M. Van Eeckhout

\section{MASTER}

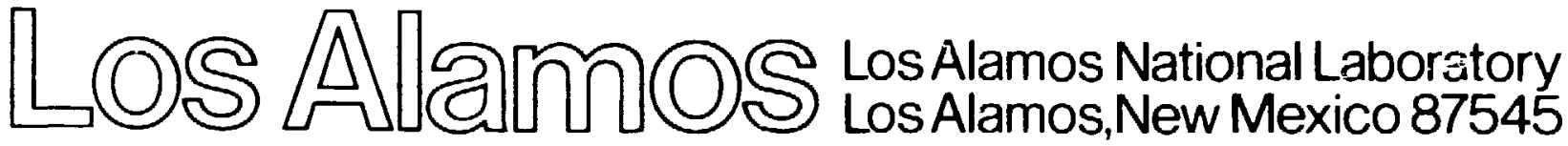




\section{DISCLAIMER}

This report was prepared as an account of work sponsored by an agency of the United States Government. Neither the United State Government nor any agency thereof. nor any of their employees, makes any warranty, express or implied, or assumes any legal liability or responsibility for the accuracy, completeness, or usefulness of any information, apparatus, product, or process disclosed, or represents that its use would not infringe privately owned rights. Reference herein to any specilic commercial product, process, or service by trade name, trademark, manufacturer, or otherwise does not necessarily constitute or imply its endorsement. recommendation, or favoring by the United States Government or any agency thereof. The views and opinions of authors expressed herein do not necessarily state or reflect those of the United States Government or any agency ihereof. 
CONTENTS

Page

LIST OF ILLUSTRATIONS . . . . . . . . . . . . . . . . vi

LIST OF TABLES . . . . . . . . . . . . . . . . . . . . viji

ABSTRACT . . . . . . . . . . . . . . . . . . . . 1

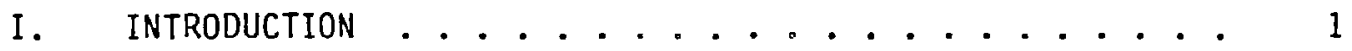

II. SUMMARY ......................... 3

III. RECOMMENDED SPECIFICATIONS FOR CONTROLLED BLASTING • . . 4

IV. ROCK FRAGMENTATION FOR UNDERGROUND OPENINGS . . . . . . . 5

A. Charge Calculations and the Drilling Pattern . . . 8

B. Controlled Blasting Techniques .......... 14

V. MONITORING TECHNIQUES . . . . . . . . . . . . . 26

REFERENCES ....................... 30 
1. Stratigraphy of exploratory shaft (after Los Alamos

Page National Laboratory 1984; Bentley 1984) ........ 2

2. Map of the Nevada Test Site and vicinity, showing Yucca Mountain and other sites (from Stock et al. 1985, p. 8692)

3. Idealized schematic of fracturing induced by explosive detonation in a borehole (from Hoek and Brown 1980, p. 367).................. . . 6 6

4. Various sections of a drift separated according to blast design (from Holmberg 1982, p. 182)........

5. Specific charge as a function of tunnel area (fron Holmberg 1982, p. 1582).............

6. Typical burn cuts used in underground mining (from

E. I. duPont 1980, p. 251) .......... 10

7. A burn cut blast round (from E. I. duPont 1980,

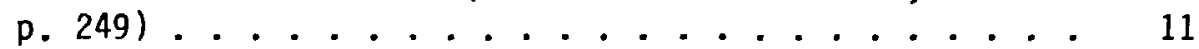

8. Typical fan or $V$-cuts used in underground mining (from Hoek and Brown 1980, pp. 368-369) ........

9. A pyramid cut round in a circular shaft (from E. I. dupont 1980, p. 363) . . . . . . . .

10. A typical drift round in medium-hard rock using a fourhole vertical $V$-cut with two-hole baby $V$-cut and millisecond-delay electric caps (from E. I. duPont 1980, p. 257) ................ . .

11. Theory of presplitting (from E. I. duPont 1980, p. 374)

12. Plexiglass model of presplitting (from Langefors and Kihlstrom 1978, p. 298) .............

13. Presplitting example (spacing $=0.7 \mathrm{ft}$., diameter $=$ 1.25 in.) (from Langefors and Kihlstrom 1978, p. 299).

14. Presplitting example illustrating drilling accuracy required (from Langefors and Kihistrom 1978, p. 317) 
$\underline{\text { Page }}$

15. Well-designed round where damage is limited by smooth blasting (from Holmberg 1982, p. 1586) .......

16. Recommended charge concentration and hole diameters for smooth blasting using two Swedish explosives (from Holmberg 1982, p. 1586) .............

17. Smooth blasting in Swedish power station (from Langefors and Kihlstrom 1978, p. 319;........

18. Final contours formed by smooth blasting, Swedish power station (from Langefors and Kihlstrom 1978, p. 321). . .

19. Peak particie velocities at various distances from a borehole charge with different densities (from Hoek and Brown 1980, p. 372) ............. 22

20. Average disturbance depths for various controlled blasting techniques experienced in eight tests (from Worsey 1985, p. 1139) . . . . . . . . . 23

21. Example of acceleration registration and resulting particle velocity close to detonating charge (from Holmberg and Persson 1979, p. 282) . . . . . 28

22. Seismic profile equation for determining depth of disturbance using seismic refraction (from Worsey 1985, p. 1134) . . . . . . . . . 
Page

I. SOME EXPLOSIVE WEIGHT STRENGTHS (after Holmberg 1982 , p. 1581, and Holmberg 1983, p. 27). . . . . . 7

II. EXPLOSIVE ROCK CONSTANTS FOR VARIOUS ROCK TYPES (from Holmberg 1983, p. 12) ............. 8

III. SOME RECOMMENDATIONS FOR SMOOTH BLASTING (from Hoek and Brown 1980, p. 374) ............. 19

IV. SOME RECOMMENDATIONS FOR PRESPLIT BLASTING (from Oriard 1982 p. 1592). . . . . . . . . . 20

V. FURTHER RECOMMENDATIONS FOR SMOOTH BLASTING AND PRESPLITTING (from Langefors and Kinlstrom 1978, p. 310) ...................... 20

VI. TYPICAL PUBLISHED VALUES FOR THE CONSTANTS $k, \alpha$, AND $\beta$ (from Hoek and Brown 1980, p. 379) .......... 23

VII. CASE HISTORIES OF BLAST DAMAGE MEASURED IN TUNNELS (after Kelsall 1986). .................. 24 


\section{CONTROLLED BLASTING AND ITS IMPLICATIONS}

FOR THE NNWSI PROJECT EXPLORATORY SHAFT

by

Edward M. Van Eeckhout

ABSTRACT

This report reviews controlled blasting techniques for shaft sinking. Presplitting and smooth blasting are

the techniques of principal interest. Smooth blasting is preferred for the Nevada Nuclear Waste Storage Investigations exploratory shaft. Shaft damage can be monitored visually or by peak velocity measurements and refractive techniques. Damage into the rock should be limited to $3 \mathrm{ft}$.

\section{INTRODUCTION}

This report reviews contrclled blasting techniques that are appropriate for shaft-sinking operations at Yucca Mountain, Nevada, a potential repository for high-level nuclear waste. These studies are being coordinated under the Nevada Nuclear Waste Storage Investigations (NNWSI) Project managed by the Waste Management Project Office of the US Department of Energy. The principal concern is the extent of overbreak damage to the in-situ rock mass, particularly that affecting permeability surrounding the shaft, and ways of quantifying that damage.

Specific questions to be addressed are:

1. How extensive is the damage from various controlled blasting techniques--which is the best?

2. What monitoring techniques might be used for quality assurance?

3. How tight should the specifications be for damage control? 
The proposed depth of the NNWSI shaft is $1480 \mathrm{ft}$ in Yucca Mountain in Nevada (see Fig. 1 for the conceptual drawing). The stratigraphic rock sequence is also shown in Fig. 1. The shaft will have a diameter of $12 \mathrm{ft}$ and will be concrete lined. Figure 2 is a map of the Nevada Test Site and shows Yucca Mountain.

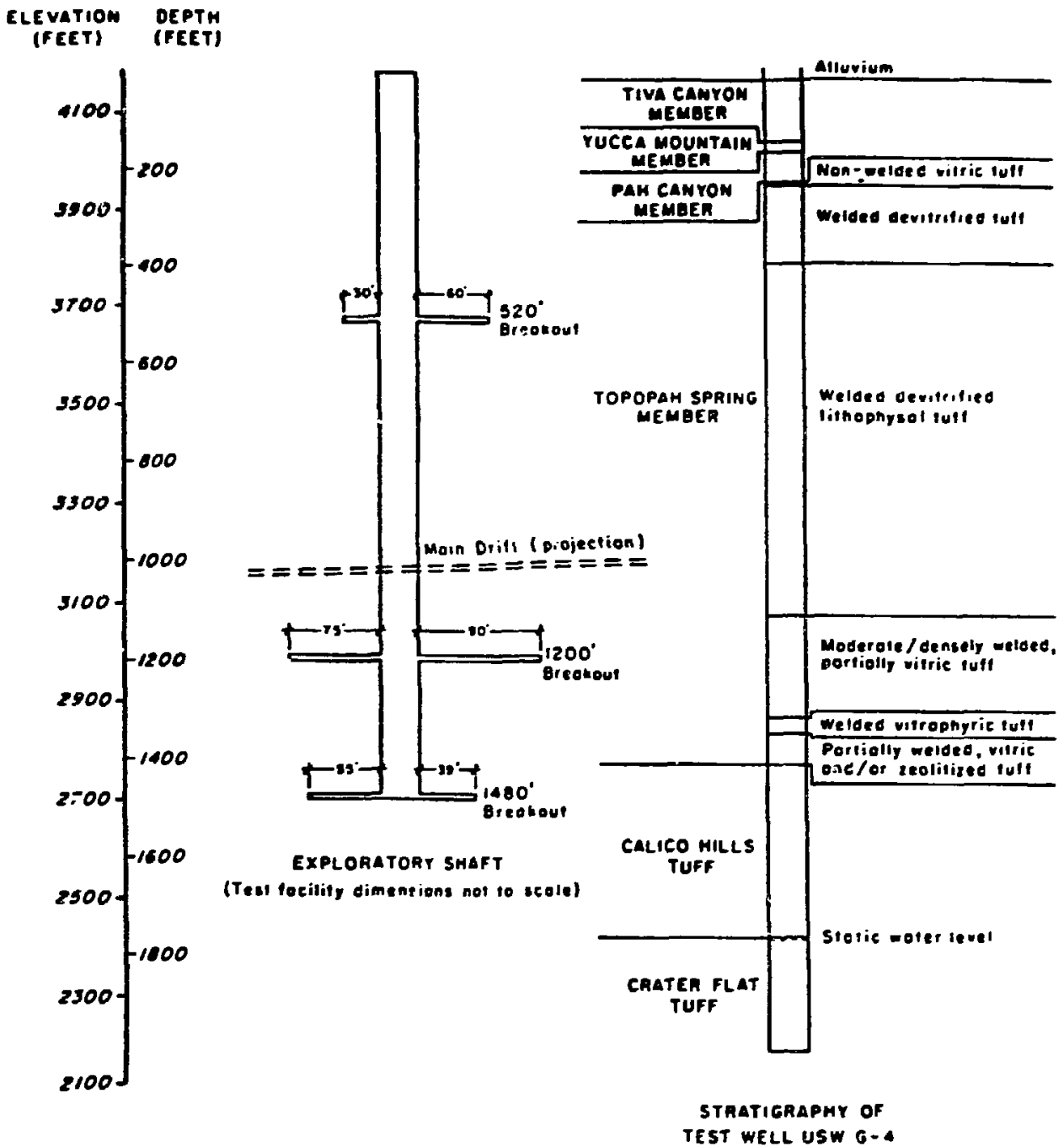

Fig. 1. Stratigraphy of exploratory shaft (after Los Alamos National Laboratory 1984; Bentley 1984). 


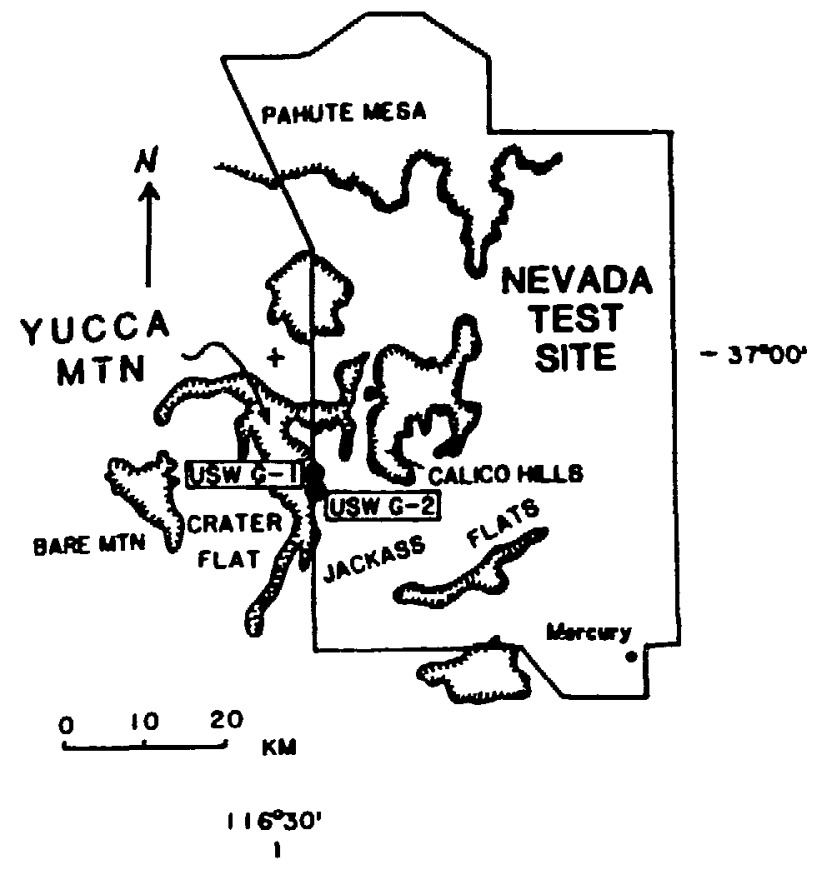

Fig. 2. Map of the Nevada Test Site and vicinity, showing Yucca Mountain and other sites (from Stock et a1. 1985, p. 8692).

II. SUMMARY

We review two common controlled blasting techriques used for driving underground openings, smooth wall and presplitting. For this appiication smooth-wall blasting is preferred, given the fact that two separate blasts are required for presplitting. Presplitting would require considerable time and coordination during a shaft-sinking operation, but it does appear to yield less damage than smooth-wall blasting.

Because there is no all-encompassing formula that can be used throughout an entire shaft-sinking operation for a 11 rock types, we recommend that certain leeway should be given to the blasting contractor in the shaftsinking specifications. However, clear quality control checks should be provided on peak particle velocity (maximum of $2.75 \mathrm{in.} / \mathrm{s}$ or $700 \mathrm{~mm} / \mathrm{s}$ ) in rock and on depth of rock breakage (a value of $3 \mathrm{ft}$ or $1 \mathrm{~m}$ is clearly achievable). 
Peak particle velocity is the most monitored characteristic of a blast. Velocity monitors can be installed on the surface, in the shaft, and in vertical boreholes near the shaft if necessary. A threshold of $2.75 \mathrm{in.} / \mathrm{s}$ or $700 \mathrm{~mm} / \mathrm{s}$ has of tentimes been used to mark the onset of rock damage. This threshold is much larger than that cited in WIPP specifications for concrete damage ( $5 \mathrm{in./s}$ ) (Cottle 1985). If $5 \mathrm{in./s}$ is used, in situ rock damage should be minimized.

Actual rock breakage can be monitored by borescopes or seismic refraction techniques. The former requires extra boreholes, whereas the latter can be done along the shaft perimeter. Seismic refraction appears to be a good way to monitor and measure the depth of rock breakage.

\section{RECOMMANDED SPECIFICATIONS FOR CONTROLLED BLASTING}

The following is recommended:

1. Smonth-wall blasting is the preferred controlled blasting technique for shaft sinking.

2. Because rock damage can be limited to less than $3 \mathrm{ft}$ by controlled blasting techniques, a tolerance of $3 \mathrm{ft}$ of damage is recommended (to be checked by refractive techniques).

3. Blasts should be monitored by means of particle velocity checks in the shaft as well as on the surface. 
Fragmenting of rock to minimize damage to underground openings is a well-developed art form and science. Blind application of design formulas will result in optimal results in certain rock types, but not so in others. Thus, a blasting foreman must be allowed certain flexibility for changing a blast design within certain limits. Those limits can be described using scientific and empirical guidelines that are well established in the blasting literature. A review of that literature leads us to our ultimate goal in this report: guidelines for specifications to minimize damage around an exploratory shaft.

The vary nature of blasting will, of course, cause damage to the rock nlass surrounding an opening. Figure 3 illustrates the basic principles of fragmentation surrounding a detonated hole. The explosive load or charge required (expressed in terms of explosive weight/hole length) varies depending upon whether the rock needs to be pulverized or rock damage needs to be minimized. If controlled blasting (the term implies minimal rock damage) is used, the hole will be lightly loaded or charged and the distance (spacing) between holes will be decreased.

Specific round designs (a round is simply one fragmentation or blast sequence) depend upon the rock mass encountered, the explosive used, the ultimate application for the opening, and the available equipment for drilling. One normally starts the design by first considering the drilling equipment (particularly hole diameters available) and then choosing the explosive diameters appropriate (if in cartridge form).

Explosives for underground use are generally termed "high explosives" (sensitive to a No. 8 blasting cap) with powder factors of 1.5 to $12 \mathrm{lb} / \mathrm{yd}^{3}$ (the powder factor is the weight of explosive per unit volume broken) as opposed to surface use explosives with powder factors of 0.4 to $21 \mathrm{~b} / \mathrm{yd}^{3}$ (Hoek and Bray 1977, p. 286). ANFO (ammonium nitrate fuel oil), a low explosive, can be used underground if there is no water present (given its sensitivity to water). 


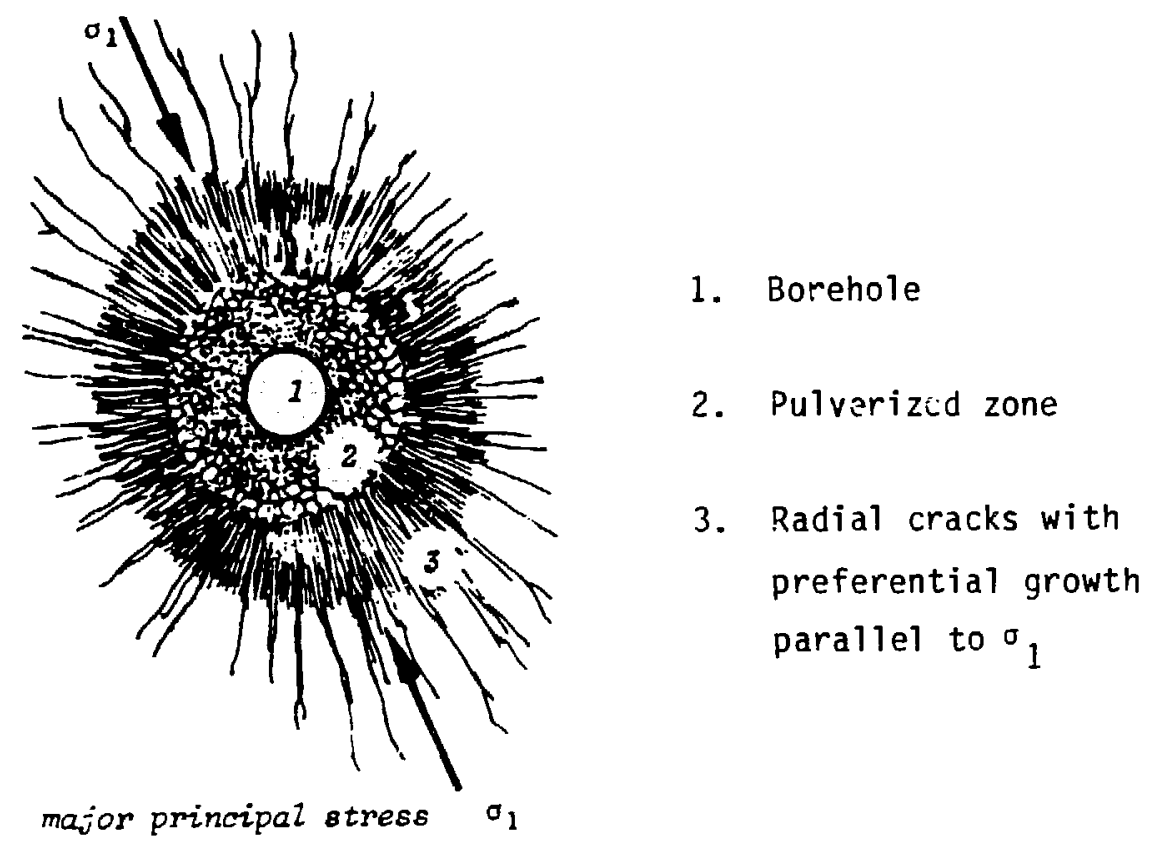

Fig. 3. Idealized schematic of fracturing induced by explosive detonation in a borehole (from Hoek and Brown 1980, p. 367).

Explosives can be compared by strength, sensitivity, density, detonation velocity, water resistance, fume class, detonation pressure, borehole pressure, cost and by other classifications (see Dick et al. 1983, Chapter 1, for a detailed discussion), but the Swedish weight strength method described by Holmberg $(1982,1983)$ is perhaps most utilized. This relationship is given as follows:

$$
S=\frac{5}{6} \frac{Q}{Q_{0}}+\frac{1}{6} \frac{V}{V_{0}}
$$

where

$$
\begin{aligned}
S= & \text { weight strength relative to a reference explosive (LFB } \\
& \text { dynamite, a Swedish dynamite), } \\
Q_{0}= & \text { heat of explosion for } 1 \mathrm{~kg} \text { of } L F B,
\end{aligned}
$$


$V_{0}=$ released gas volume from $1 \mathrm{~kg}$ of $L F B$ at standard temperature and pressure,

$Q=$ heat of explosion from $1 \mathrm{~kg}$ of the actual explosive, and

$V=$ released gas volume from $1 \mathrm{~kg}$ of the astual explosive.

The factors $5 / 6$ and $1 / 6$ were experimentally determined by field tests. Some explosive weight strengths so calculated, and converted to compare with ANFO, are listed in Table I.

TABLE I. SOME EXPLOSIVE WEIGHT STRENGTHS

(after Holmberg 1982, p. 1581, and Holmberg 1983, p. 27)

\begin{tabular}{lllll} 
EXPLOSIVE & $\begin{array}{c}Q \\
(M \mathrm{~J} / \mathrm{kg})\end{array}$ & & $\left.\mathrm{m}^{3} \mathrm{~V} / \mathrm{kg}\right)$ & \multicolumn{1}{c}{$S_{\text {ANFO }}$} \\
\cline { 2 - 2 } LFB dynamite & 5.00 & & 0.850 & 1.19 \\
ANFT & 3.9 & 0.973 & 1.00 \\
TNT & 4.1 & 0.690 & 0.98 \\
PETN & 6.12 & 0.780 & 1.39 \\
GURIT & 3.73 & 0.425 & 3.85 \\
NABIT & 4.10 & 0.892 & 1.02 \\
Tovex 100 & 3.2 & 0.90 & 0.85 \\
Tovex 210 & 3.65 & 0.85 & 0.92 \\
Tovex 220 & 3.7 & 0.78 & 0.93
\end{tabular}

The weight strength of the explosive chosen and the charge concentration (weight per unit hole length) can then be used to calculate burden and spacing (distance to free face and between holes, respectively) by various empirical formulas in the literature (e.g., Hemphill 1981).

Another factor used in many of the design formulas is a measure of rock blastability. In Swedish formulas (see Langefors and Kihlstrom 1978, pp. 43-44), a constant $c$ is introduced as a measure of explosives per cubic meter of rock to be broken. Some values for $c$ from their scheme are given in Table II. 
TABLE II. EXPLOSIVE ROCK CONSTANTS FOR VARIOUS ROCK TYPES

(from Holmberg 1983, p. 12)

\begin{tabular}{ll} 
C VALUE \\
ROCK TYPE & $\left(\mathrm{kg} / \mathrm{m}^{3}\right)$ \\
\hline
\end{tabular}

Brittle crystalline granite

0.2

Most other rocks

$0.3-0.4$

Most Swedish granite

0.4

It is unclear how these values might extrapolate to the Nevada Test Site rocks, but that does not need to be addressed at this point. Some American formulas for production burden and spacing use specific gravity of the rock mass (see Hemphil1 1981, pp. 94-95). Production blasting is less sensitive to rock type than controlled blasting.

\section{A. Charge Caiculations and the Drilling Pattern}

Rather than specifically going through charge calculations for typical headings, we summarize some considerations. There are numerous examples given in Holmberg (1982), Gustafsson (1981, Chap. 9), and Langefors and Kihlstrom (1978, Chaps. 7-8), which are generally European examples. Most American examples tend to be even more general and empirical (see, for example, E. I. dupont 1980, Chaps. 16 and 20; Hemphill 1981, Chap. 12). Non-availability of American examples is primarily due to the free enterprise competitiveness between companies.

An underground drift is typically divided into five sections for design purposes (see Fig. 4); design calculations are different for each section. Section A of Fig. 4 (the cut), along with sections $B, C$, and $E$ will be considered first. Discussions of Section $D$ will follow (in the controlled blasting portion of this report). The outline of the opening will be circular instead of horseshoe shaped in our application, but many of the same principles apply to either situation. Also, it might be pointed out that the specific charge (or overall powder factor) will vary 
with the tunnel (shaft) area as shown in Fig. 5. For example, a 12-ft-diameter shaft $\left(10.5 \mathrm{~m}^{2}\right)$ might require on the order of a $3 \mathrm{~kg} / \mathrm{m}^{3}$ powder factor.

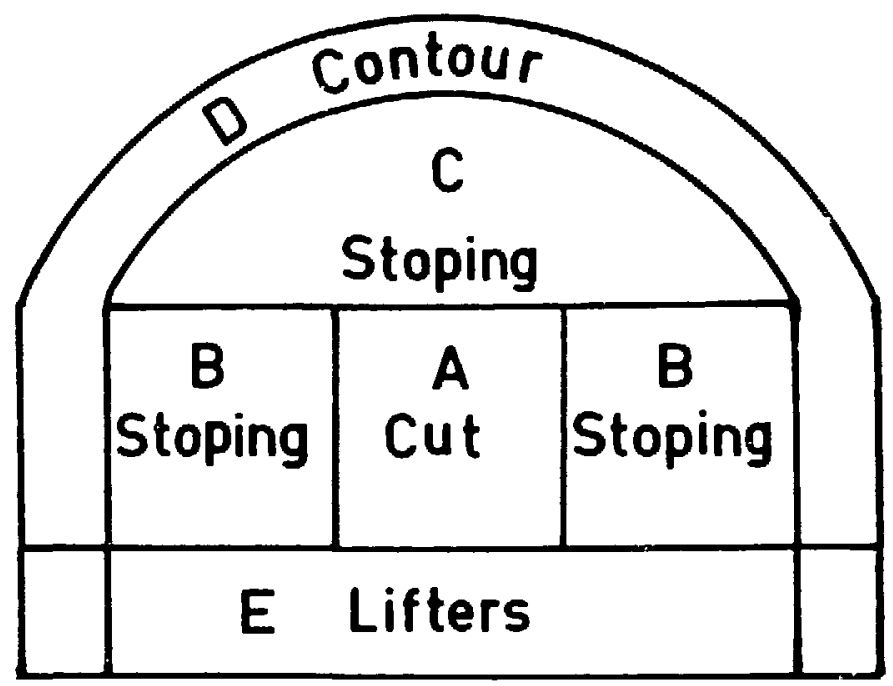

Fig. 4. Various sections of a drift separated according to blast design (from Holmberg 1982, p. 1582).

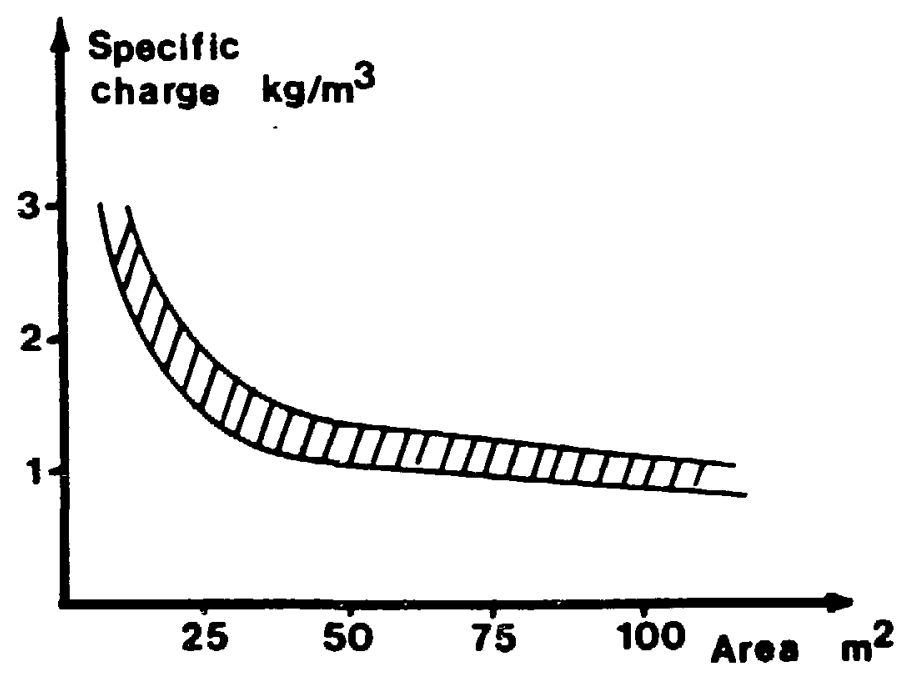

Fig. 5. Specific charge as a function of tunnel area (from Holmberg 1982, p. 1582) 
The first and most important task in disigning a successful blast round is the creation of a free face, for each hole has to have a free surface to break to. To accomplish that, a "free face" has to be introduced by drilling parallel empty holes (a "burn" cut) or angled holes (a "V," "fan," or "wedge" cut). Thus, rock will be broken into the empty holes or out to the drift face. Example burn cut patterns are shown in Fig. 6, and an overall burn cut blast pattern is shown in Fig. 7. Example fan and V-cut patterns are shown in Fig. 8, and an overall "pyramid" blast pattern is shown in Fig. 9.
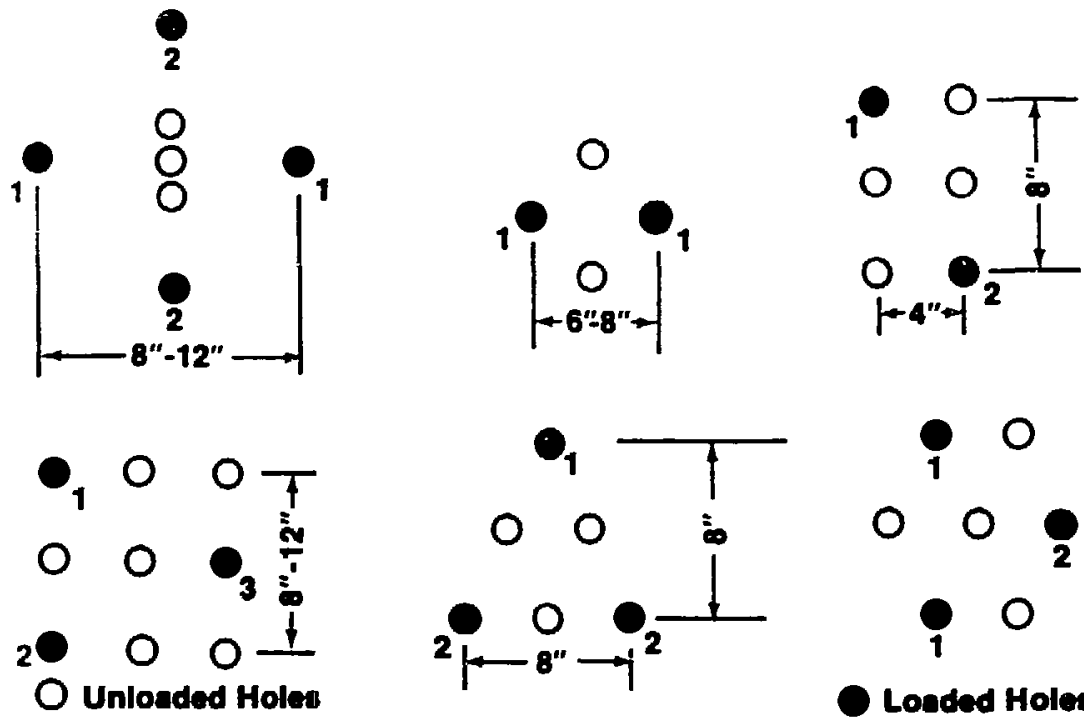
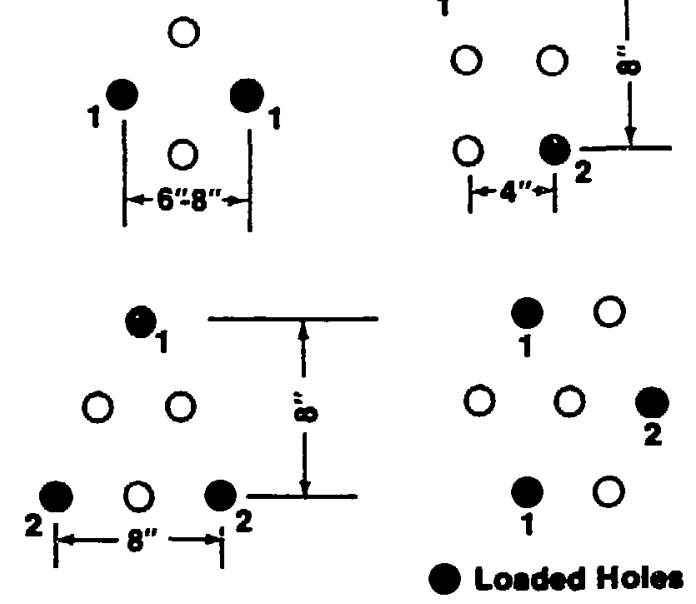

Fig. 6. Typical burn cuts used in underground mining (from E. I. duPont 1980, p. 251). 


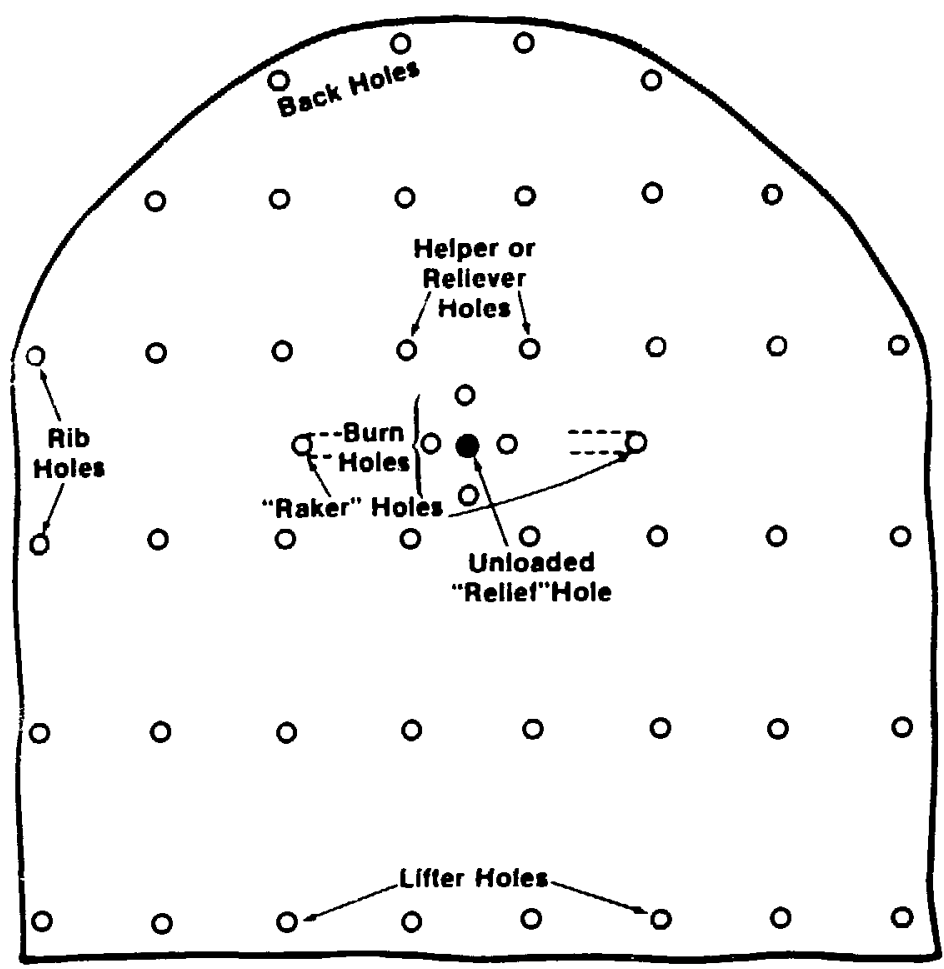

Fig. 7. A burn cut blast round (from E. I. duPont 1980, p. 249).

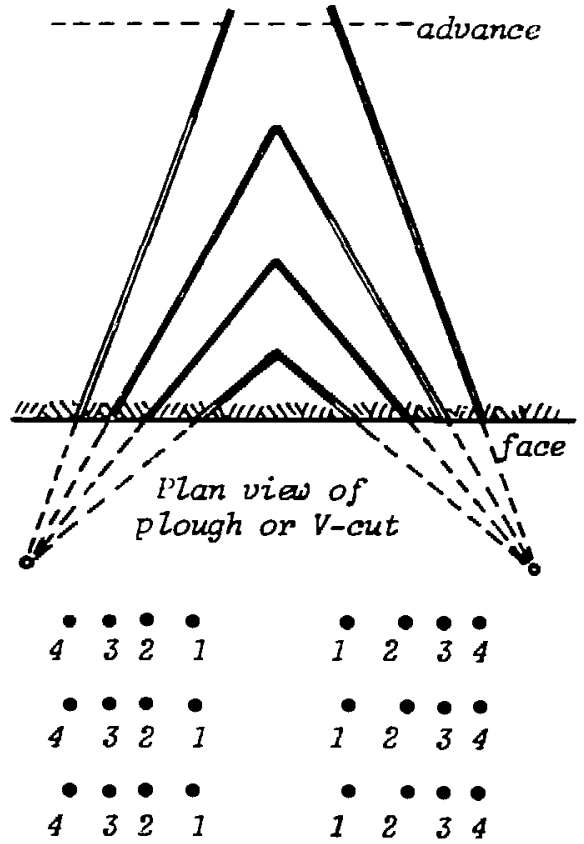

Face view and initiation sequence
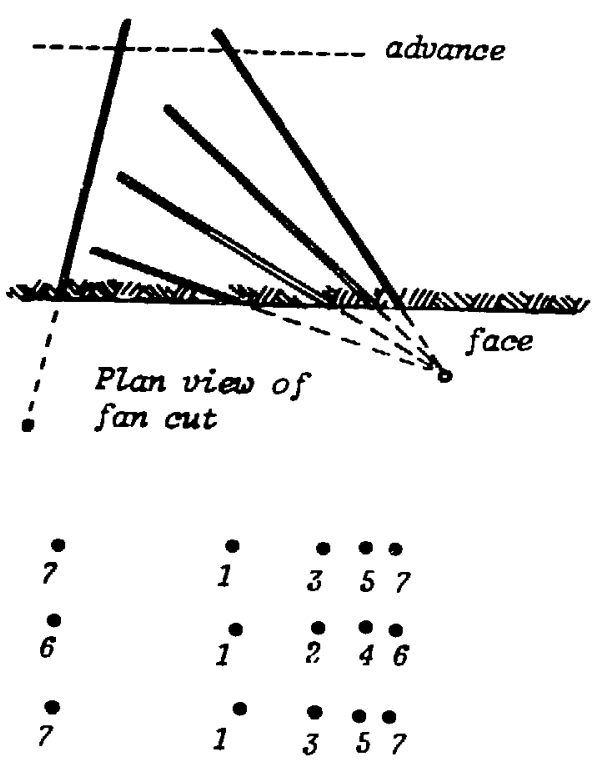

Face vies showing typical initiation sequence

Fig. 8. Typical fan or V-cuts used in underground mining (from Hoek and Brown 1980, pp. 368-369). 


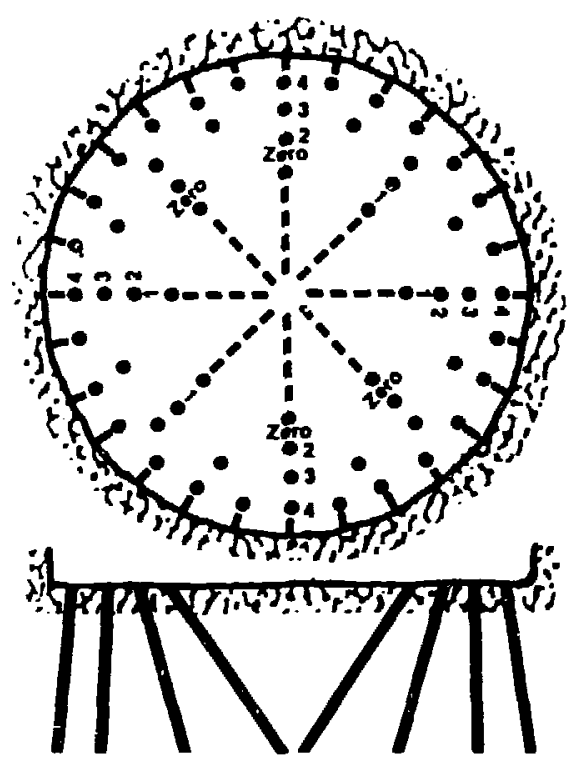

Fig. 9. A pyramid cut round in a circular shaft (from E. I. duPont 1980, p. 363).

For a burn cut, a minimum of $15 \%$ of the area influenced by the first holes to fire must be left open for rock to expand into. The burn cut is a popular method of creating volume to expand into. The angle cut is also popular (epecially in its ability to "throw" the rock--although fragmentation is not as even) but more room is required for drilling machine maneuverability. Successive delayed holes are detonated later than the first initial cut, somewhat akin to that shown in Fig. 10. 

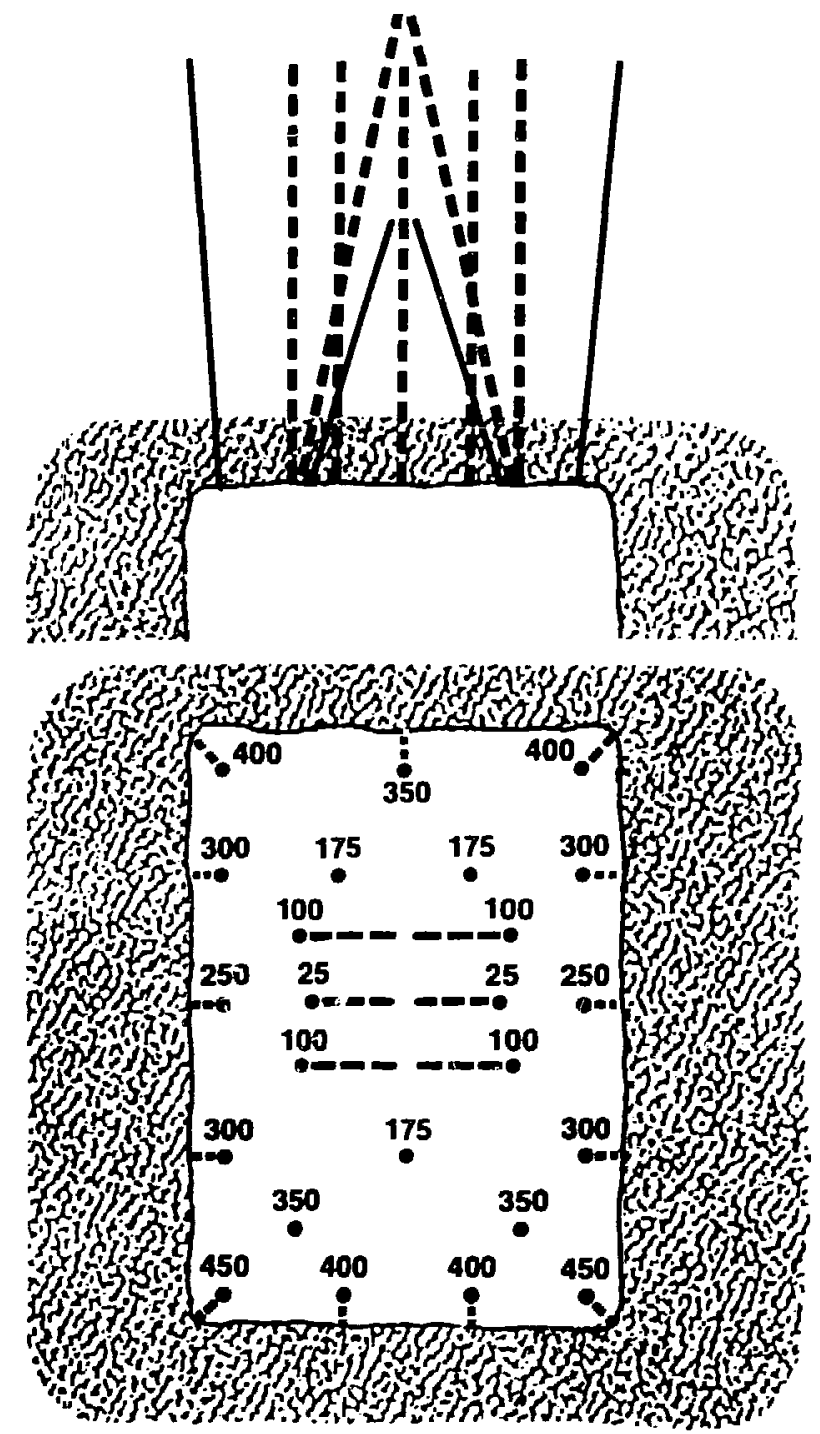

Fig. 10. A typical drift round in medium-hard rock using a four-hole vertical $V$-cut with a two-hole baby $V$-cut and millisecond-delay electric caps (from E. I. dupont 1980, p. 257). 


\section{B. Controlled Blasting Techniques}

In underground environments, two controlled blasting techniques are common: presplitting and smooth blasting. Presplitting is the method of lightly loading perimeter holes and setting off charges within them before the production blast. The shock waves between holes interact and break the rock in tension as shown in Fig. 11. An example in a plexiglass model is shown in Fig. 12, and a specific field example is shown in Fig. 13. Results are generally very good but are a function of drilling accuracy (see Fig. 14 for a demonstration of accuracies sometimes required) and fracture density in the rock mass. One problem in using this specific method underground is that two separate blasts have to be set off, which is cumbersome for scheduling purposes. Smooth blasting doesn't have such problems.

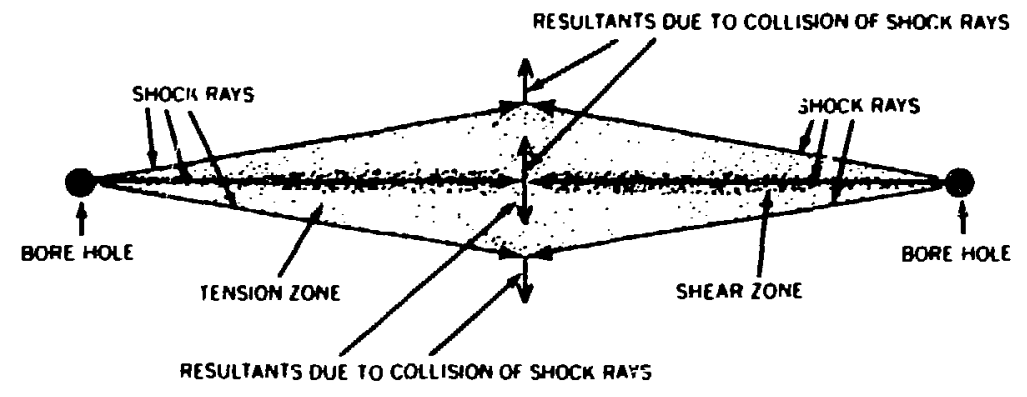

NOTE IF HOLES ARE ONERLOADED SHEAR ZONE WILL EXIEND TO AND BE YOND INDCAIED IENSION ZONE

Fig. 11. Theory of presplitting (from E. I. duPont 1980, p. 374 ). 


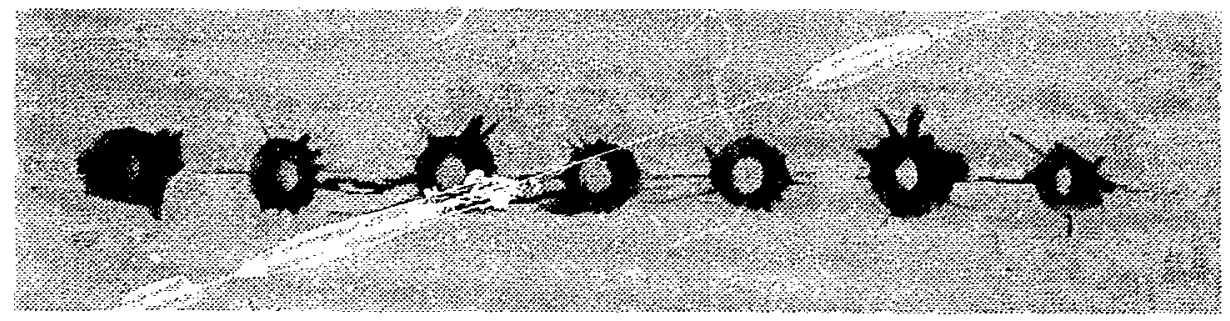

Fij. 12. Plexiglass model of presplitting (from Langefors and Kihlstrom 1978 , p. 278).

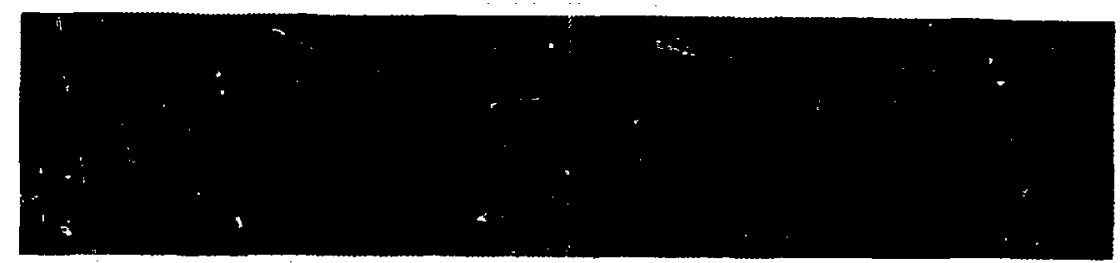

Fig. 13. Presplitting example (spacing $=0.7 \mathrm{ft}$, diameter $=1.25$ in.) (from Langefors and Kihistrom 1978, p. 299).

Smooth-blasting is a method whereby holes are loaded lighter and spaced closer around the perimeter and then shot as the last delay of the round. No presplit face is left to reflect shock waves, so sometimes damage is a bit more than presplitted. Damage can be limited by design. "Buffer" holes (between the main production portion of the blast and the perimeter holes) are loaded so that damage doesn't extend farther than the perimeter holes (see Fig. 15). Minimum charge requirements for two Swedish explosives are shown in Fig. 16, while some results are shown in Figs. 17 and 18; some design parameters for smooth blasting and presplitting are shown in Tables III, IV, and $V$ (note $E=$ spacing and $V=$ burden in Table V). 


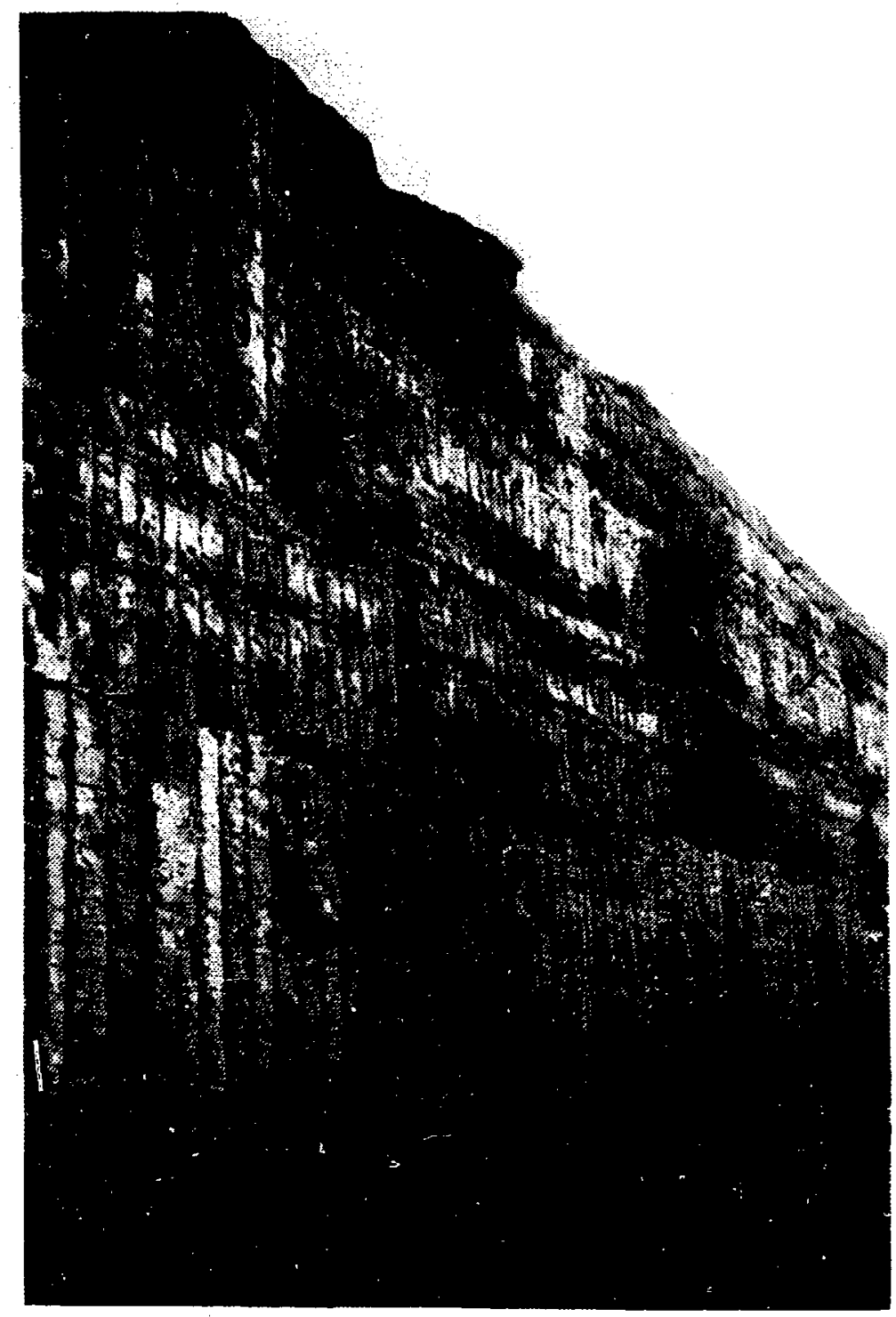

Fig. 14. Presplitting example illustrating drilling accuracy required (from Langefors and Kihlstrom 1978, p. 317). 


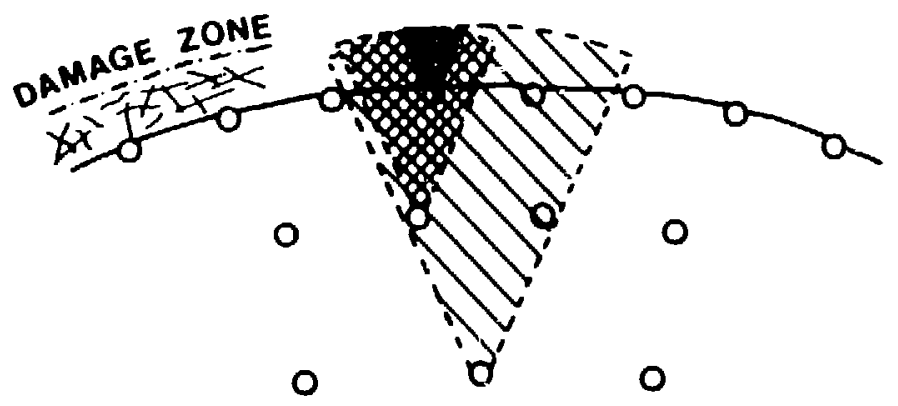

Fig. 15. Well-designed round where damage is 1 imited by smooth blasting (from Holmberg 1982, p. 1586).

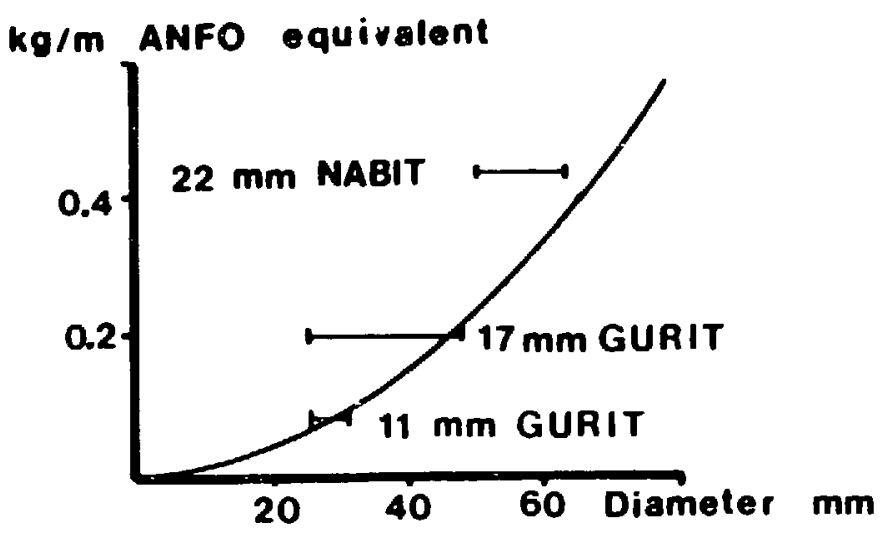

Fig. 16. Recommended charge concentration and hole diameters for smooth blasting using two Swedish explosives (from Holmberg 1982, p. 1586). 


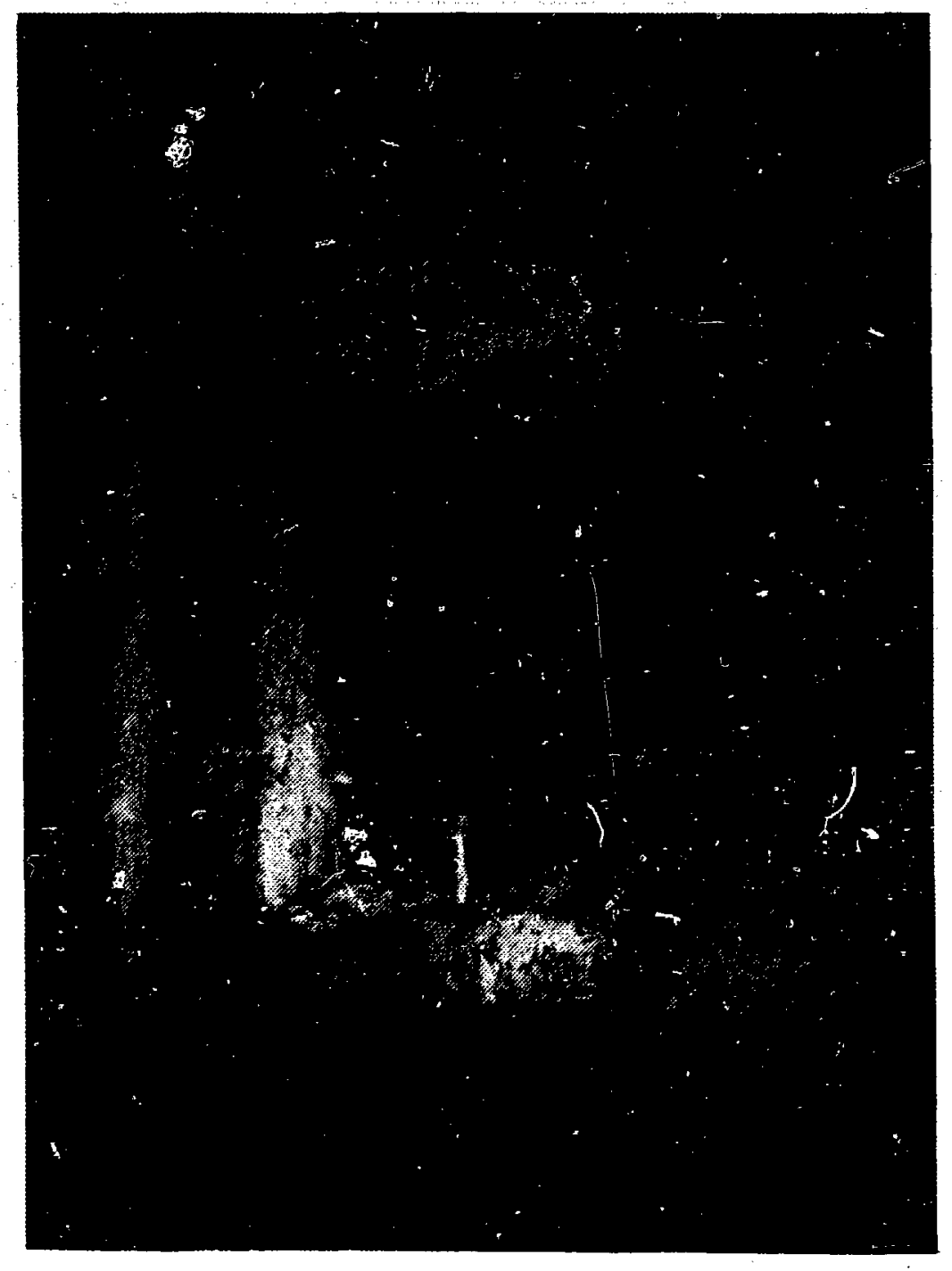

Fig. 17. Smooth blasting in Swedish power station (from Langefors and Kihlstrom 1978, p. 319). 


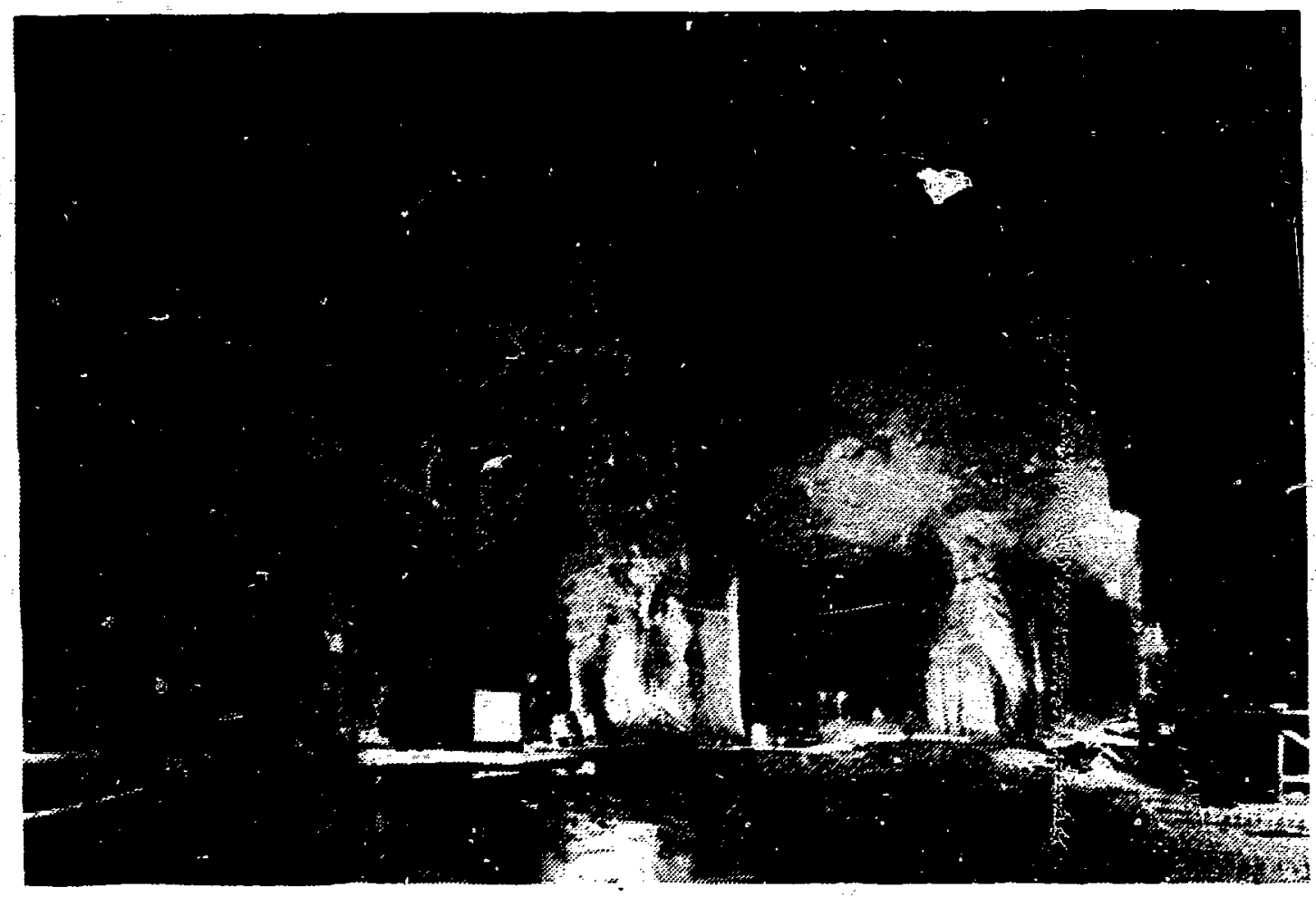

Fig. 18. Final contours formed by smooth blasting in Swedish power station (from Langefors and Kihlstrom 1978, p. 321).

TABLE III. SOME RECOMHENDATIONS FOR SMOOTH BLASTING (from Hoek and Brown 1980, p. 374)

\begin{tabular}{|c|c|c|c|c|}
\hline $\begin{array}{l}\text { Orill Hole } \\
\text { Diameter } \\
(\mathrm{mm}))\end{array}$ & $\begin{array}{c}\text { Charge } \\
\text { Diameter } \\
(\mathrm{mm})\end{array}$ & $\begin{array}{c}\text { Charge } \\
\text { Concentration } \\
(\mathrm{kg} \mathrm{ANFO} / \mathrm{m})\end{array}$ & $\begin{array}{l}\text { Burden } \\
\text { (m) }\end{array}$ & $\begin{array}{l}\text { Spacing } \\
\text { (m) }\end{array}$ \\
\hline $\begin{array}{l}25-32 \\
25-48 \\
57-64\end{array}$ & $\begin{array}{l}11 \\
17 \\
22\end{array}$ & $\begin{array}{l}0.08 \\
0.20 \\
0.44\end{array}$ & $\begin{array}{l}0.30-0.45 \\
0.70-0.90 \\
1.00-1.10\end{array}$ & $\begin{array}{l}0.25-0.35 \\
0.50-0.70 \\
0.08-0.90\end{array}$ \\
\hline
\end{tabular}


TABLE IV. SOME RECOMMENDATIONS FOR PRESPLIT BLASTING (from Oriard 1982, p. 1592)

\begin{tabular}{|c|c|c|c|c|c|}
\hline \multicolumn{2}{|c|}{ Hole Diameter } & \multicolumn{2}{|c|}{ Spacing } & \multicolumn{2}{|c|}{ Charge Concentration } \\
\hline (in.) & $(m m)$ & $(f t)$ & $(\mathrm{mm})$ & $(1 b / f t)$ & $(\mathrm{kg} / \mathrm{m})$ \\
\hline $\begin{array}{r}21 / 2-3 \\
4 \\
6 \\
8\end{array}$ & $\begin{array}{r}64-76 \\
102 \\
152 \\
203\end{array}$ & $\begin{array}{ll}2-3 & 1 / 2 \\
3-4 & \\
4-6 & \\
6-8 & \end{array}$ & $\begin{array}{l}0.6-1.1 \\
0.9-1.2 \\
1.2-1.8 \\
1.8-2.4\end{array}$ & $\begin{array}{l}0.18-0.25 \\
0.25-0.50 \\
0.35-0.75 \\
0.75-1.50\end{array}$ & $\begin{array}{l}(0.02-0.035) \\
(0.03-0.50) \\
(0.05-0.10) \\
(0.10-020)\end{array}$ \\
\hline
\end{tabular}

TABLE V. FURTHER RECOMMENDATIONS FOR SMOOTH BLASTING AND SPLITTING (from Langefors and Kihlstrom, 1978, p. 310)

Drill Hole Concentration

\begin{tabular}{|c|c|c|c|c|c|c|c|c|}
\hline \multicolumn{2}{|c|}{$\begin{array}{c}\text { Diameter } \\
\mathrm{d}\end{array}$} & \multicolumn{2}{|c|}{$\begin{array}{c}\text { of Charge } \\
e\end{array}$} & \multicolumn{3}{|c|}{ Smooth } & \multicolumn{2}{|c|}{$\begin{array}{c}\text { Presplitting } \\
\mathrm{E}_{1}\end{array}$} \\
\hline $\mathrm{mm}$ & (in.) & $\mathrm{kg} / \mathrm{m}$ & $(1 \mathrm{~b} / \mathrm{ft})$ & Charge Units ${ }^{a}$ & ${ }^{\tau_{1}}$ & 1 & m & $(f t)$ \\
\hline 30 & $1 / 2)$ & & & Gurit & 0.5 & 0.7 & $0.25-0$ & $\left(\begin{array}{ll}1-1 & 1\end{array}\right)$ \\
\hline 37 & $1 / 2)$ & 0.12 & 0.0 & Gur & & 0. & & $\begin{array}{lll}1-1 & 1\end{array}$ \\
\hline 44 & (1 $3 / 4)$ & 0.17 & & Gurit & 0.6 & 0 . & 0.3 & $1 /$ \\
\hline 50 & (2) & 0.25 & $(0.17)$ & Gurit & 0.8 & 1. & $0.45-0.70$ & $(11 / 2-2)$ \\
\hline 62 & $21 / 2)$ & 0.35 & 10 & Nabit $22 \mathrm{~mm}$ & & 1. & .80 & $(2-2 \quad 1)$ \\
\hline 75 & (3) & 0.5 & & Nabit $25 \mathrm{~mm}$ & 1 & 1 . & & \\
\hline 87 & (3 $1 / 2)$ & 0.7 & 10. & Dynamite $25 \mathrm{~mm}$ & 1.4 & 1. & 0.7 & 12 \\
\hline & & 0.9 & & Dynamite $29 \mathrm{~mm}$ & 1. & & & \\
\hline & $(5$ & 1.4 & & Nabit $40 \mathrm{~mm}$ & & 1 . & & \\
\hline & (6) & 2.0 & & Nabit $50 \mathrm{~mm}$ & 2.4 & 3. & $1.2-1.8$ & $(4-6)$ \\
\hline & (8) & 3.0 & $(2.0)$ & Dynamite $52 \mathrm{~mm}$ & 3.0 & 4.0 & $1.5-2.1$ & $(5-7)$ \\
\hline
\end{tabular}

a If no special charges are available, dynamite taped on detonating cord to a concentration $1 \mathrm{~kg} / \mathrm{m}(1 \mathrm{~b} / \mathrm{ft})$ can be used. 
Rock damage surrounding a blast hole is oftentimes correlated with peak particle velocity (Holmberg 1982, p. 1586; Hoek and Prown 1980, p. 371) by an empirical equation:

$$
v=\frac{k W^{\alpha}}{R^{B}}
$$

where

$$
\text { where } \quad \begin{aligned}
V= & \text { the peak particle velocity, } \mathrm{mm} / \mathrm{s}, \\
W= & \text { weight charge, } \mathrm{kg}, \\
R= & \text { distance from detonation, and } \\
k, a, \text { and } B= & \text { constants that are functions of the structural and } \\
& \text { elastic properties of the rock mass. }
\end{aligned}
$$

Holmberg (1982) suggests values of $k=700, \alpha=0.7$, and $\beta=1.5$ for tunneling in competent Swedish rock. Other values of these constants have been suggested by various workers (see Table VI). However, a value of between 700 and $1000 \mathrm{~mm} / \mathrm{s}$ has been accepted as being the onset of damage to rock. Calculations using Eq. (2) with the velocity criteria overlaid are given in Fig. 19. Thus, a $45-\mathrm{mm}$ blasthole with a charge density of 1.5 $\mathrm{kg} / \mathrm{m}$ has a $1.5-\mathrm{m}$ damage radius. Lower densities result in less damage.

It appears from the case histories described in Table VII that damage from perimeter holes varies from 1 to $6 \mathrm{ft}$, depending upon the method. The best that can be expected in terms of damage (measured by direct borehole sheervations or peak particle velocity gauges) is $1 \mathrm{ft}$. One result of interest is shown in Fig. 20, which shows damage measured (by refractive techniques) for specific rounds. These case histories showed that presplitting controlled blasting had minimal damage. However, presplitting is a more cumbersome method to use. 


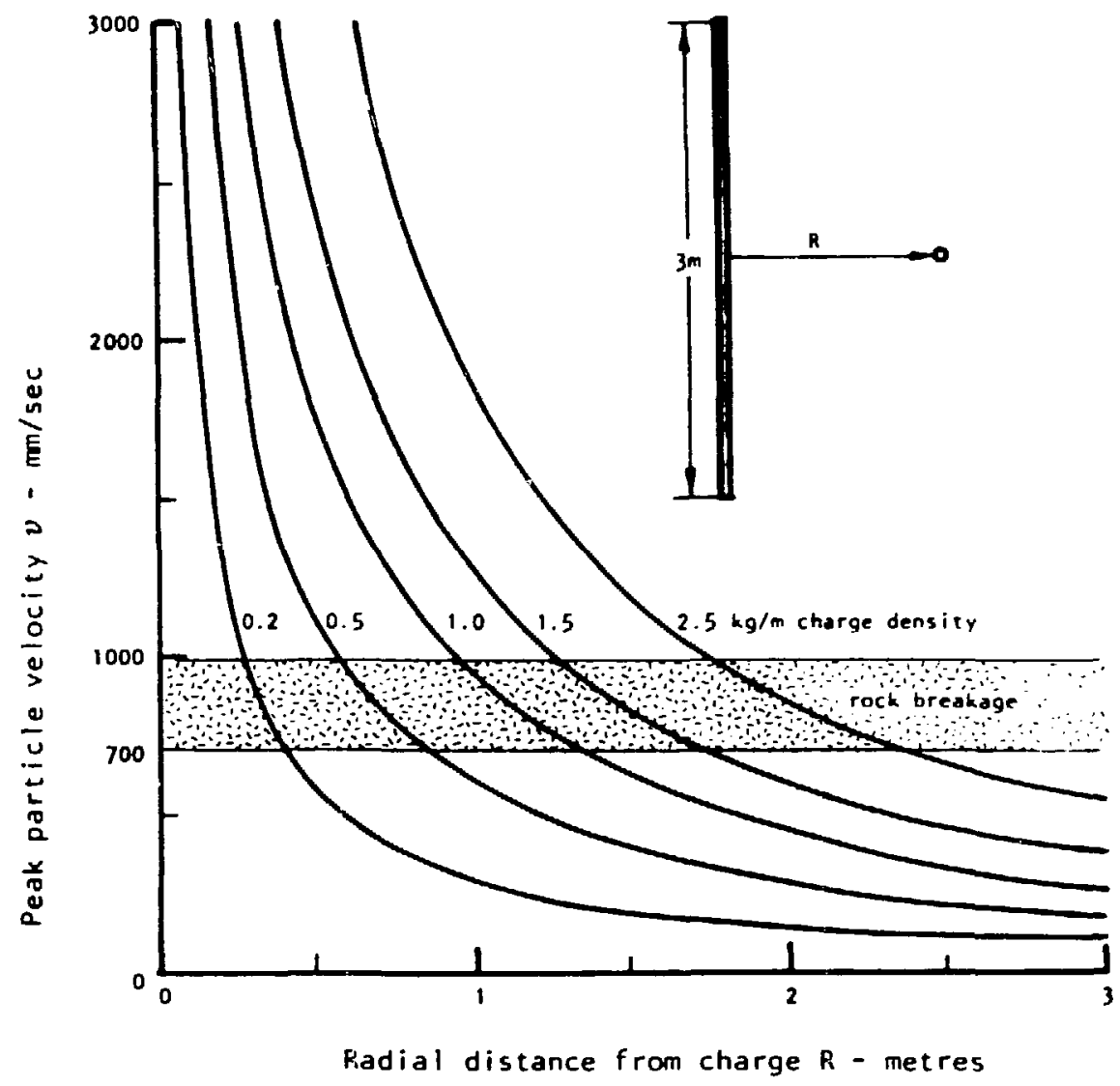

Fig. 19. Peak particle velocities at various distances from a borehole charge with different densities (from Hoek and Brown 1980, p. 372). 
TABLE VI. TYPICAL PUBLISHED VALUES FOR THE CONSTANTS $k, a$, and $\beta$ (after Hoek and Brown 1980, p. 379)

\begin{tabular}{|c|c|c|c|c|c|}
\hline \multicolumn{2}{|r|}{$k^{\mathrm{a}}$} & \multirow{2}{*}{$\frac{\alpha}{0.66}$} & \multirow{2}{*}{$\frac{\beta}{1.54}$} & Conditions & Reference \\
\hline & 730 & & & & Lundborg et a1. (1978) \\
\hline 2 & 083 & 0.53 & 1.60 & $\mathrm{R} / \mathrm{w}^{1 / 3} 3$ & Ambraseys and Hendron (1968) \\
\hline 11 & 455 & 0.53 & 2.80 & $R / \mathrm{H}^{1 /} 3$ & Ambraseys and Hendron (1968) \\
\hline 1 & 686 & 0.71 & 1.78 & & Holmberg (1979) \\
\hline & 707 & 0.68 & 1.56 & & Vorb'ev et a1. (1972) \\
\hline & 700 & 0.70 & 1.50 & Average Swedish bedrock & Holmberg and Persson (1980) \\
\hline 193 & $3-1930$ & 0.80 & 1.60 & Downhole bench blasting & Oriard (1972) \\
\hline & $7-148$ & 0.55 & 1.10 & Coyote blasting ${ }^{b}$ & Oriard (1972) \\
\hline & 958 & 0.80 & 1.60 & Presplit blasting & Oriard (1972) \\
\hline
\end{tabular}

${ }^{a}$ To calculate the particle velocity $v$ in in./s for a distance $R$ in $\mathrm{ft}$ from a charge of $W$ Tb of explosive, divide $k$ by 7.42 and use the same vaiues for $\alpha$ and $B$.

b Coyote blasting involves placing a large concentration of explosives in a tunnel or cavity. It is used to loosen large volumes of rock close to surface.

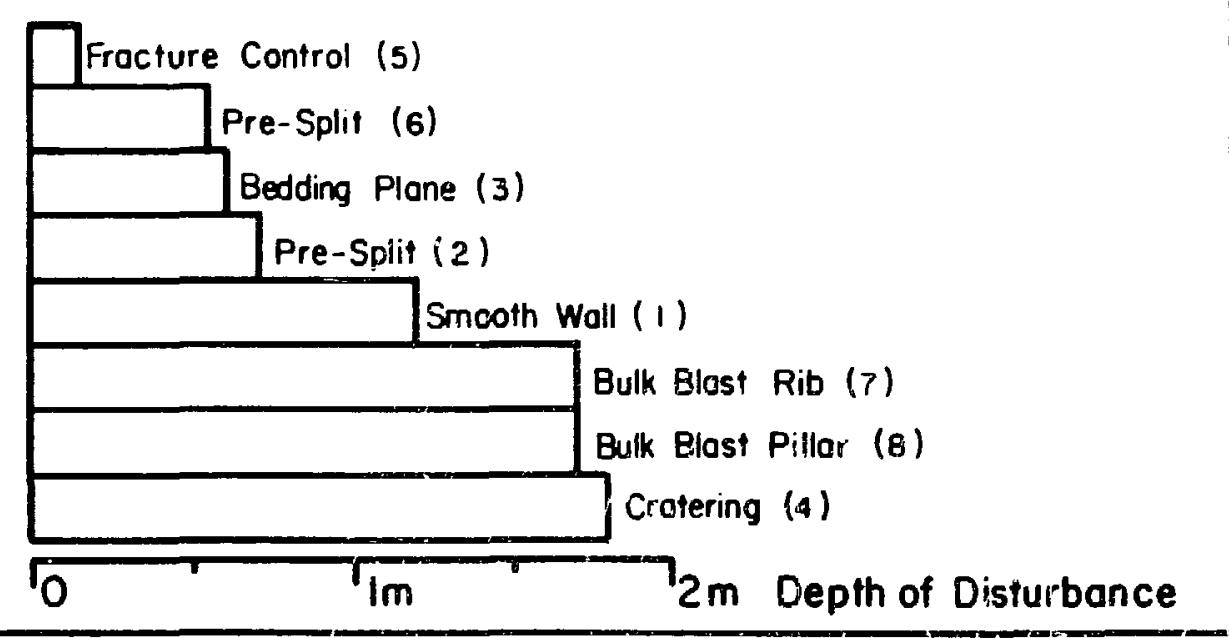

Fig. 20. Average disturbance depths for various controlled blasting techniques experienced in eight tests (from Wor sey 1985, p. 1139). 
TABLE VII. CASE HISTORIES OF BLAST DAMAGE MEASURED IN TUNNELS (after Kelsall, 1986)

\begin{tabular}{|c|c|c|c|c|}
\hline SITE & $\begin{array}{l}\text { ROCK } \\
\text { TYPE } \\
\end{array}$ & $\begin{array}{l}\text { BLASTING } \\
\text { METHOD }\end{array}$ & $\begin{array}{c}\text { TUNNEL } \\
\text { DIMENSIONS } \\
\end{array}$ & $\begin{array}{l}\text { DEPTH DF } \\
\text { DAMAGE }\end{array}$ \\
\hline $\begin{array}{l}\text { Colorado School } \\
\text { of Mines } \\
\text { (Edgar Mine) } \\
\text { Colorado }\end{array}$ & $\begin{array}{r}\text { Biotite } \\
\text { gneiss }\end{array}$ & Smoothwa11 & $5 m \times 3 n$ & $0.5 \mathrm{~m}$ \\
\hline $\begin{array}{l}\text { Stripa Mine } \\
\text { Sweden }\end{array}$ & Granite & Smoothwal1 & $4 m \times 4 m$ & $0.3 m$ \\
\hline $\begin{array}{l}\text { Rainier Mesa } \\
\text { Nevada Test }\end{array}$ & $\begin{array}{l}\text { Zeolitized } \\
\text { tuff }\end{array}$ & Conventional & $3 m$ & $<1.7$ m (?) \\
\hline $\begin{array}{l}\text { Rolla } \\
\text { Experimental Mine }\end{array}$ & Dolomite & Various & $2.5 \mathrm{~m} \times 2.2 \mathrm{~m}$ & $0.3-2.5 \mathrm{~m}$ \\
\hline $\begin{array}{l}\text { Near Surface } \\
\text { Test Facility, } \\
\text { BWIP }\end{array}$ & Basalt & Conventional & $5 m$ & $2 m$ \\
\hline Ontario, Canada & Limestone & Presplit & $8 m$ & $\operatorname{lm}$ \\
\hline Saimogo, Japan & $\begin{array}{l}\text { Sandstone/ } \\
\text { shale }\end{array}$ & Conventional & $5.1 \mathrm{~m}$ & up to $1.3 \mathrm{~m}$ \\
\hline Crastmore Mine & Marble & Conventional & $30-70 \mathrm{ft}$ & $4-5 f t$ \\
\hline $\begin{array}{l}\text { Churchill Falls, } \\
\text { Canada }\end{array}$ & Gneiss & $\begin{array}{c}\text { Controlled } \\
\text { Perimeter }\end{array}$ & $2.1 \mathrm{~m} \times 2.4 \mathrm{~m}$ & $<1 m$ \\
\hline $\begin{array}{l}\text { Straight Creek, } \\
\text { Colorado }\end{array}$ & $\begin{array}{l}\text { Granite/ } \\
\text { gneiss/ } \\
\text { schist }\end{array}$ & Conventional & $4 m$ & "few $\mathrm{ft} "$ \\
\hline $\begin{array}{l}\text { Belledonne, } \\
\text { France }\end{array}$ & Granite & Conventional & $5.9 \mathrm{~m}$ & $\operatorname{lm}$ \\
\hline Mine & Shale & Conventional & $?$ & $0.5-1 \mathrm{~m}$ \\
\hline $\begin{array}{l}\text { Rama Tunnel, } \\
\text { Yugoslavia }\end{array}$ & Dolomite & Conventional & $5 m$ & $<\operatorname{lm}$ \\
\hline $\begin{array}{l}\text { Turlough Hill, } \\
\text { Ireland }\end{array}$ & Granite & Conventiona! & $2.5 \mathrm{~m}$ & $0.5-2.5 \mathrm{~m}$ \\
\hline
\end{tabular}




\begin{tabular}{|c|c|c|}
\hline MEASUREMENT METHOD & COMMENTS & REFERENCES \\
\hline $\begin{array}{l}\text { Borehole logging, } \\
\text { cross-hole permeability } \\
\text { (packer tests). } \\
\text { borehole deformation }\end{array}$ & $\begin{array}{l}\text { Deptil of blast damage not well } \\
\text { documented but in agreement } \\
\text { with theoretical calculations }\end{array}$ & $\begin{array}{l}\text { Montazer and } \\
\text { Hustrulid, } 1983\end{array}$ \\
\hline Boreholes & $\begin{array}{l}0.1-1.0 \mathrm{~m}, 0.3 \mathrm{~m}=\text { average; } \\
\text { permeability of blast } \\
\text { damaged zone not measured }\end{array}$ & $\begin{array}{l}\text { Anderson and } \\
\text { Halen, } 1978\end{array}$ \\
\hline Air permeability & $\begin{array}{l}\text { Blast damage not well distin- } \\
\text { guished from stress effects }\end{array}$ & $\begin{array}{l}\text { Miller et al., } \\
1974\end{array}$ \\
\hline Seismic refraction & $\begin{array}{l}\text { Depth of damage varies accord- } \\
\text { ing to method used; blast } \\
\text { damage not distinguished from } \\
\text { stress relie? }\end{array}$ & Worsey. 1985 \\
\hline Cross-hole seismic & $\begin{array}{l}\text { 9last damage seen most clearly } \\
\text { in vertical trave } 1 \text { direction } \\
\text { in drift wail, effects of } \\
\text { stress relief seen in hori- } \\
\text { zontal direction }\end{array}$ & $\begin{array}{l}\text { King et a } 1 \ldots \\
1994\end{array}$ \\
\hline $\begin{array}{l}\text { TV camera in boreholes } \\
\text { in crown }\end{array}$ & $\begin{array}{l}\text { Separate zones of moderate } \\
\text { cracking and hairline cracks; } \\
\text { depth of damage varies with } \\
\text { charge weight }\end{array}$ & Lukajic, 1982 \\
\hline Seismic refraction & $\begin{array}{l}\text { Comparison of blasting with } \\
\text { excavation by TBM; difficult } \\
\text { to separate blast damage } \\
\text { from stress relief }\end{array}$ & $\begin{array}{l}\text { Nishiida et } \\
\text { a1., } 1982\end{array}$ \\
\hline $\begin{array}{l}\text { Seismic refraction, } \\
\text { borehole jack, } \\
\text { borehole logging }\end{array}$ & & $\begin{array}{l}\text { Heuze and } \\
\text { Goodman, } 1974\end{array}$ \\
\hline Plate load test & Most damage within $0.3 \mathrm{~m}$ & $\begin{array}{l}\text { Benson et } \\
\text { al., } 1978\end{array}$ \\
\hline Selsmic refraction & $\begin{array}{l}\text { Blast damage depth estima- } \\
\text { ted ithin overall low velor } y \\
\text { layer extending } 1-5 \mathrm{~m}\end{array}$ & $\begin{array}{cl}\text { Scott et } \\
\text { a } 1.1 & 1963\end{array}$ \\
\hline Seismic refraction & $\begin{array}{l}\text { Blasting and stress relief } \\
\text { effects not specifically } \\
\text { distinguished }\end{array}$ & Plichon, 1980 \\
\hline Seismic refraction & $\begin{array}{l}\text { Blasting and stress relief } \\
\text { effects not specifically } \\
\text { distinguished }\end{array}$ & $\begin{array}{l}\text { Brizzolari, } \\
1981\end{array}$ \\
\hline Cross-hole seismic & $\begin{array}{l}\text { Blasting and stross relief } \\
\text { effects not specifically } \\
\text { distinguished }\end{array}$ & $\begin{array}{l}\text { Kujundizet } \\
\text { a1., } 1970\end{array}$ \\
\hline Cross-hole seismic & $\begin{array}{l}\text { Blasting and stress relief } \\
\text { effects not speciffcally } \\
\text { distinguished }\end{array}$ & $\begin{array}{l}\text { O'Danoghue and } \\
\text { O'Flaherty. } \\
1974\end{array}$ \\
\hline
\end{tabular}


There is a well-developed literature concerning blast damage monitoring, particularly for damage to nearby structures. Good references are Bollinger (1980), Dowding (1985), and Hanna (1985). Specific case studies dealing with blast damage monitoring in undergrjund settings are summarized in Tabie VII. One additional study that has been published subsequent to that compilation is given by Rustan et al. (1985). Their study indicates that damage can be limited to 0.1 to $0.7 \mathrm{~m}$ into the rock, depending upon the controlled blasting method. These values were obtained by vibration monitoring and borehole viewing, two common methods of assessing damage. One other method used is the seismic refraction technique (Worsey 1985). These are the three methods we discuss in this section.

Vibration monitoring is perhaps the most common monitoring technique. Peak particle velocity is the most common entity monitored since damage is the result of induced strain $\varepsilon$, which is a function of the peak particle velocity $v$ as follows:

$$
\varepsilon=v / c
$$

where $c$ is a characteristic propagation velocity. A value of $700 \mathrm{~mm} / \mathrm{s}$ has been quoted for the onset of damage (Holmberg and Persson 1979; Dowding 1985) and seems to correlate well with damage observed visually (with borehole viewing). For example, Rustan et al. (1985) showed the following correlation between the two: 


\begin{tabular}{lc}
\multicolumn{2}{c}{ Damage Limit, $\mathrm{m}^{\mathrm{a}}$} \\
$\begin{array}{l}\text { Vibration } \\
\text { Monitoring }\end{array}$ & $\begin{array}{r}\text { Borehole } \\
\text { Viewing }\end{array}$ \\
\hline 0.1 & 0.4 \\
0.25 & 0.3 \\
0.3 & 0.5 \\
0.55 & 0.7 \\
0.6 & 0.75
\end{tabular}

\begin{abstract}
aVibration damage limit set at $700 \mathrm{~mm} / \mathrm{s}$; periscope monitoring damage limit set at distance where more than three cracks develop per meter.
\end{abstract}

Vibration monitors can be placed on the surface, attached to a structure or in boreholes close to the area of interest. Results observed (see Fig. 21 for an example) can then be correlated to the explosive site by an appropriate distance scaled law.

For the NNWSI site, no further holes in the vicinity of the shaft are desired, so monitoring in this manner would be limited to the surface, in the shaft itself, or perhaps in existing boreholes near the shaft.

Borehole viewing can also be used but requires another hole be drilled for the viewing operation. This seems unacceptable in the application under discussion and is thus discarded.

The final technique that has been used for damage assessment is seismic refraction. This method relies upon waves being propagated faster in unbroken material, with the depth of broken material being calculated from an intersection of time/distance curves (see Fig. 22). This method requires a series of geophones laid out along the shaft wall and would be a good method for assessing damage after-the-fact. 

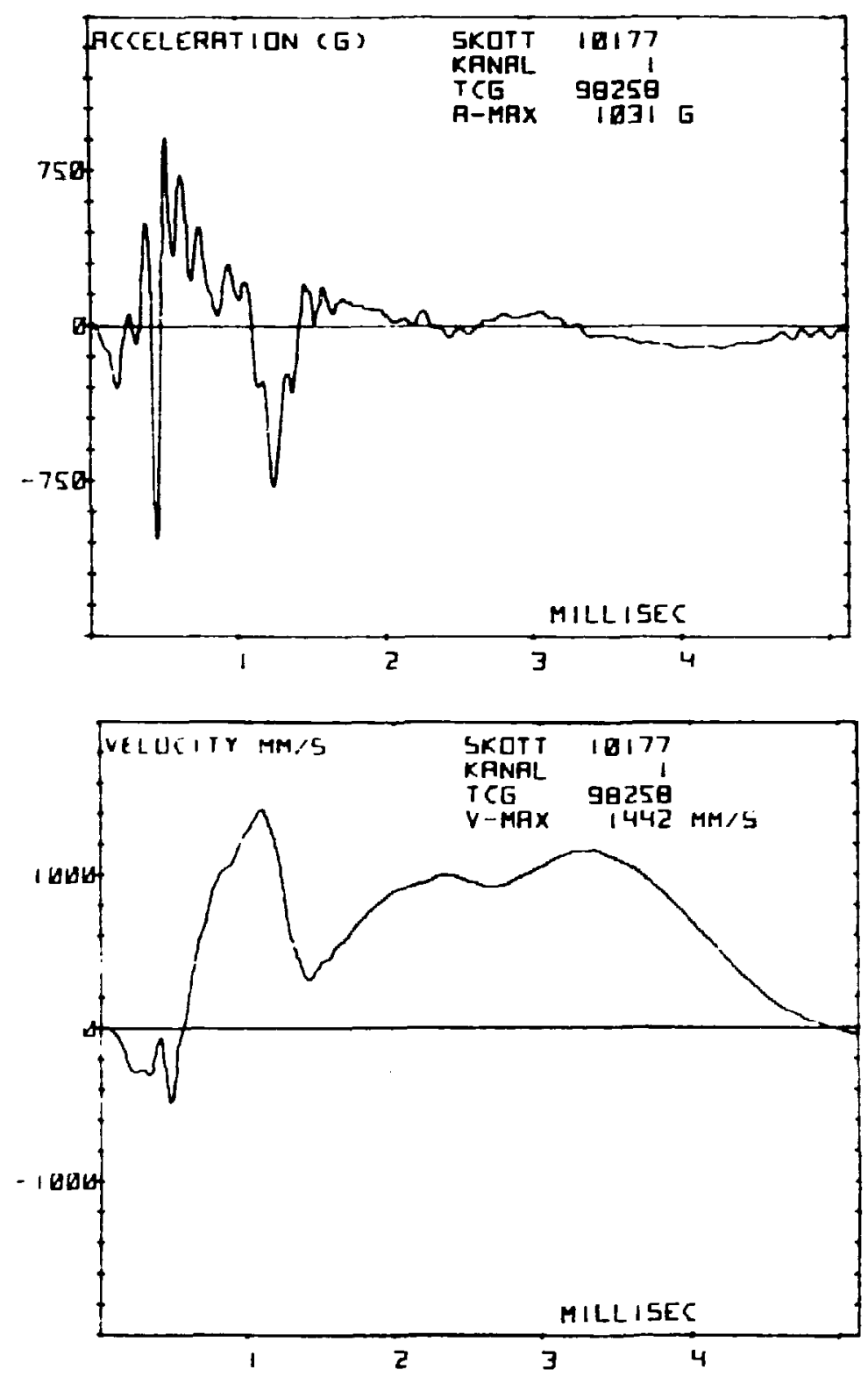

Fig. 21. Example of acceleration registration and resulting particle velocity close to detonating charge (from holmberg and Persson 1979, p. 282). 

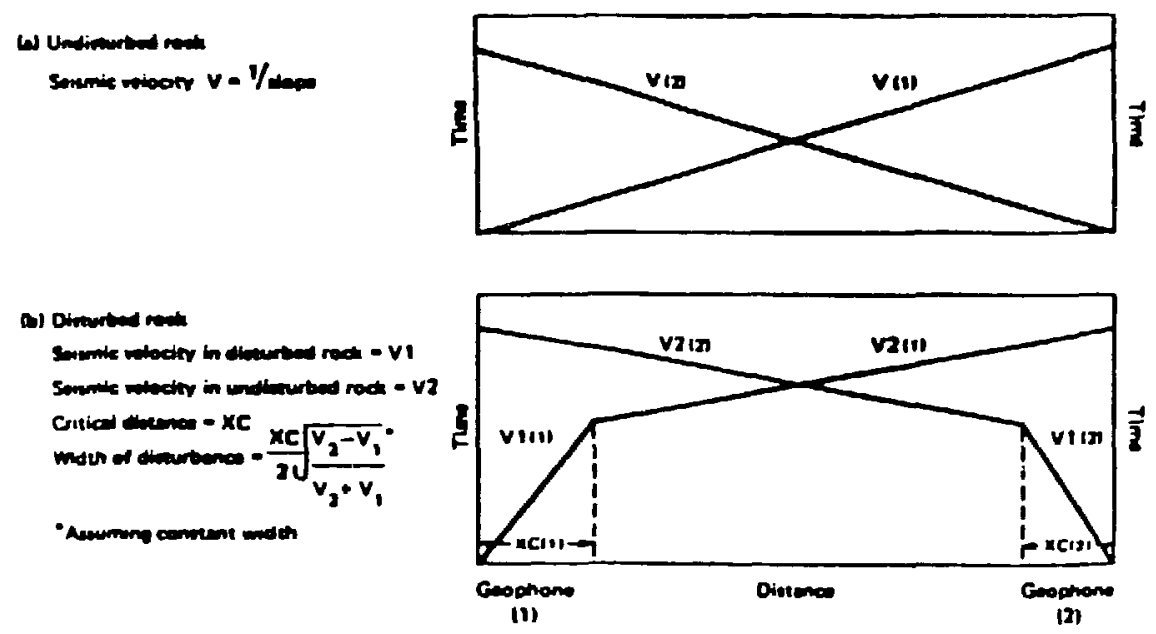

Fig. 22. Seismic profile equation for determining depth of disturbance using seismic refraction (from Worsey 1985, p. 1134).

We conclude that the best monitoring techniques to use in the NNWSI exploratory shaft would be "remote" velocity monitors in an array of some sort, with damage threshold at $700 \mathrm{~mm} / \mathrm{s}$, and seismic refraction to verify depth-of-damage. 
Abraseys, N. and Hendron, A., 1968, "Dynamic Behavior of Rock Masses," in Rock Mechanics in Engineering Practice, Stagg and Zienkiewicz, Eds. (John Wiley \& Sons, Inc., New York), pp. 203-236.

Anderson, B., and Halen, P. A., 1973, "Mining Methods Used in the Underground Tunnels and Test Rooms at Stripa," Lawrence Berkeley Laboratory report LBL-7081.

Benson, R. P., Murphy, D. K., and McGreath, D. R., 1978, "Modulus Testing of Rock at the Churchill Falls Underground Powerhouse, Labrador," Determination of the In Situ Modulus of Deformation of Rock, American Society for Testing and Materials, ASTM STP 477, pp. 89-116.

Bentiey, C. B., 1984, "Geohydrologic Data for Test Well USW-G-4, Yucca Mountain Area, Nye County, Nevada," US Geological Survey Open File Report 84-063, Denver, Colorado, 48 pp.

Bollinger, G. A., 1980, Blast Vibration Analysis (Southern Illinois University Press, Carbondale, ITTinoist, $132 \mathrm{pp}$.

Brizzolari, E., 1981, "Miniseismic Investigations in Tunnels: Methodology and Results," Geoexploration, 18, pp. 259-267.

Cottle, I.R., Office of Nuclear Waste Isolation, Columbus, Ohio, letter to T. Merson, Los Alamos National Laboratory, September 1985.

Dick, R. A., Fletcher, L. R., and D'Andrea, D. V., 1983, "Explosives and Blasting Procedures Manual," US Bureau of Mines Information Circular $8925,105 \mathrm{pp}$.

Dowding, C. H., 1985, Blast Vibration Monitoring and Control (PrenticeHal1, Inc., Englewood, New Jersey), 297 pp.

E. 1. duPont de Nemours and Co., 1980, Blasters' Handbook, 16th ed. (Explosives Products Div., E.I. duPont, Wilmington, De1aware), 494 pp.

Gustafsson, R., 1981, Blasting Technique, Dynamit Nobel Wien (Austrian edition), $327 \mathrm{pp}$.

Hanna, T. H., 1985, Field Instrumentation in Geotechnical Engineering, Trans Tech Publications, Series on Rock and Soil Mechanics, VoT. 10, 843 pp.

Hempi11, G. B., 1981, Blasting Operations (McGraw-Hill Book Co., New York), 258 pp.

Heuze, F. E., and Goodman, R. E., 1974, "The Design of 'Room and Pillar' Structures in Competent Jointed Rock. Example: The Crestmore Mine, California," Proceedings of the Second Congress of the ISRM, Belgrade, Yugoslavia, vol. 2, pp. 679-687. 
Hoek, E., and Bray, J., 1977, Rock Slope Engineering, revised second ed. (Institute of Mining and Metallurgy, London, England), $402 \mathrm{pp}$.

Hoek. E.. and Brown, E. T., 1980, Underground Excavations in Rock (Institute of Mining and Metallurgy, London, England), $527 \mathrm{pp}$.

Holmberg, R., 1979, "Results from Single Shot Ground Vibration Measurements," Swedish Detonic Research Foundation report DS 1979:9.

Holmberg, R., 1982, "Charge Calculations for Tunnelling," in Underground Mining Methods Handbook, Hustrulid, Ed. (SME of AIME, Denver, Colorado), pp. 1580-1589.

Holmberg, R., 1983, "Hard Rock Excavation at the CSM/OCRD Test Site Using Swedish Blast Design Techniques," Battelle Memorial Institute/0ffice of Crystalline Repository Development report BMI/OCRD-4(3), $103 \mathrm{pp}$.

Holmberg, R., and Persson, P., 1979, "Design of Tunnel Perimeter Blasthole Patterns to Prevent Rock Damage," Proceedings of the Second International Conference on Tunnelling (Tunnelling 79) (Institute of Mining and MetalTurgy, London, England), pp. 280-283.

Holmberg, R., and Persson, P.-A., 1980, "Design of Tunnel Perimeter Blasthole Patterns to Prevent Rock Damage," Transactions of the Institute of Mining and Metallurgy, London, England, 89, pp. A37-40.

Kelsall, P.C., IT Corp.. Albuquerque, New Mexico, letter to J.A. Fernandez, Sandia National Laboratory, January 1986.

King, M. S., Myer, L. R., and Rezowalli, J. J., 1984, "Cross-Hole Acoustic Measurements in Basalt," Proceedings of the 25th US Symposium on Rock Mechanics, Evanston, Illinois, pp. 1053-1063.

Kujundic, B., Joranovic, L., and Radosavljevic, Z., 1970, "A Pressure Tunnel Lining Using High-Pressure Grouting," (in French) Proceedings of the Second Congress of the ISRM, Belgrade, Yugoslavia, 4-66, pp. $867-381$.

Langefors, U., and Kihlstrom, B., 1978, The Modern Technique of Rock Blasting, 3rd ed. (Halsted Press, a Division of John Wiley \& Sons, Inc., New York), 438 pp.

Los Alamos National Laboratory, 1984, "Exploratory Shaft Test Plan," viewgraphs presented July 1984 at Sandia National Laboratory, Nevada Nuclear Waste Storage Investigations Project, Albuquerque, New Mexico.

Lukajic, B. J., 1982, "Geothermal Experience wi th Tunnel Portal Construction," 14th Canadian Rock Mechanics Symposium, Vancouver, Canada.

Luidborg, N., Holmberg, R., and Person, P. -A., 1978, "Relation Between Vibration, Distance and Charge Weight," Swedish Committee for Building Research report No. R11. 
Miller, C.H., Cunningham, D.R., and Cunningham, M. J., 1974, "An Air-Injection Technique to Study Intensity of Fractures Around a Tunnel in Volcanic Rock," Association of Engineering Geologists Bulletin, Vol. XI, No. 3, pp. 203-217.

Montazer, P. M., and Hustralid, W. A., 1983, "An Investigation of Fracture Permeability Around an Underground Opening in Metamorphic Rocks," Battelle Memorial Institute/Office of Crystalline Repository Development report BMI/OCRD-4(5).

Nishiida, T., Matsumura, Y., Miyanaga, Y., and Hori, M., 1982, "Rock Mechanical Viewpoint on Excavation of Pressure Tunnel by Tunne 1 Boring Machine," ISRM Symposium, Aachen, Germany, May 26-28, 1982.

O'Donoghue, L. B., and O'Flaherty, R. M., 1974, "The Underground Works in Turlough Hi11: Part I," Water Power, pp. 5-12.

Oriard, L. L., 1972, "Blasting Effects and Their Control in Open Pit Mining," Proceedings of the Second International Conference on Stability in Open Pit Mining, Vancouver, Canada, AIME, pp. 197-222.

Oriard, L. L., 1982, "Blasting Effects and Their Control," Underground Mining Methods Handbook, Hustrulid, Ed. (SME of AIME, Denver, CoTorado), pp. 1590-1603.

Plichon, J. N., 1980, "Measurement of the Thickness of the Decompressed Zone in an Excavation Under High Overburden Cover, Analysis of Tunnel Stability by the Convergence-Confinement Method," Underground Space, 4. No. 6, pp. 361-402.

Rustan, A., Naarttijarvi, T., and Ludvig, B., Dec. 1985, "Controlled Blasting in Hard Intense Jointed Rock in Tunnels," CIM Bulletin, 78, No. $884, p p$. 63-68.

Scott, J. H., Lee, F. T., Carroll, R. D., and Robinson, C. S., 1968, "The Relationship of Geophysical Measurements to Engineering and Construction Parameters in the Straight Creek Tunnel Pilot Bore, Colorado," Int. J. Rock Mech. Min. Sci., 5, pp. 1-30.

Stock, J. M., Healy, J. H., Hickman, S. H., and Zoback, M. D., 1985, "Hydraulic Fracturing Stress Measurements at Yucca Mountain, Nevada, and Relationship to the Regional Stress Field," J. Geophys. Res., 90, (B10), pp. 8691-8706.

Vorob'ev, I. T., et al., 1972, "Features of the Development and Propagation of the Rayleigh Surface Wave in the Dzhezkazgen Deposit," Sov. Min. Sci., 8, pp. 634-639.

Worsey, P. N., 1985, "In-situ Measurement of Blast Damage Underground by Seismic Refraction Surveys,"in Proceedings of the US Symposium on Rock Mechanics, Rapid City, South Dakota, pp. 1133-1140. 